\title{
An analysis of the current status and future of biosecurity frameworks for the Indonesian seaweed industry
}

\author{
Cicilia S. B. Kambey ${ }^{1,2}$ (D) Iona Campbell ${ }^{3}$ - Calvyn F. A. Sondak ${ }^{4}$ - Adibi R. M. Nor ${ }^{5}$ Phaik E. Lim ${ }^{1}$. \\ Elizabeth J. Cottier-Cook ${ }^{3}$
}

Received: 2 August 2019 / Accepted: 12 December 2019 / Published online: 2 January 2020

(C) The Author(s) 2020

\begin{abstract}
Indonesia is the world largest producer of the red seaweeds Kappaphycus and Eucheuma; however, this country is facing significant challenges such as disease outbreaks, epiphyte infestations and a loss in seedling quality. Biosecurity practices have been widely adopted in other aquaculture sectors and when enforced can help to limit the introduction and spread of diseases and pests. To assess current capacity for biosecurity in seaweed aquaculture in Indonesia, a systematic analysis of policy frameworks including legislation, regulatory tools, and national standards was conducted. Biosecurity themes and risks were used to evaluate current national biosecurity content. The results identified major challenges faced by the industry in order to implement biosecurity policies in practice. Barriers to implementation included unspecific reference to the seaweed aquaculture sector, limited variety of approaches to biosecurity, limited use of up-to-date scientific evidence, insufficient guidance for the use of precaution and insufficient inclusion of specific biosecurity hazards. In general, although national regulations are currently under revision, current policies indicate a lack of clarity where biosecurity is included. Six recommendations are suggested to incorporate proactive biosecurity actions into current frameworks, with the aim of improving the health and sustainability of the seaweed aquaculture sector in Indonesia.
\end{abstract}

Keywords Biosecurity $\cdot$ Indonesia $\cdot$ Seaweed aquaculture $\cdot$ Kappaphycus $\cdot$ Eucheuma $\cdot$ Legislation $\cdot$ Policy

\section{Introduction}

Seaweed aquaculture has been practiced for over five decades in Indonesia following the introduction of the red

Electronic supplementary material The online version of this article (https://doi.org/10.1007/s10811-019-02020-3) contains supplementary material, which is available to authorized users.

Cicilia S. B. Kambey

cicilia_kambey@um.edu.my; cicilia_kambey@yahoo.com

1 Institute of Ocean and Earth Sciences, University of Malaya, Kuala Lumpur, Malaysia

2 Division of Earth and Environmental Science, Oceanography Major, Pusan National University, Busan Metro City 46241, Republic of Korea

3 Blue Economy, Scottish Association for Marine Science, Oban, Argyll PA37 1QA, UK

4 Faculty of Fisheries and Marine Science, Sam Ratulangi University, Manado 95115, Indonesia

5 The International Institute of Public Policy and Management, University of Malaya, 50603 Kuala Lumpur, Malaysia carrageenan-producing species Eucheuma sp. and Kappaphycus spp. in the late 1960s and 1980s, respectively (Hurtado et al. 2016; Neish et al. 2017). Production of this crop increased exponentially and Indonesia is currently the largest global producer of these species, with a total production of 10.11 million tonnes fresh weight $(\mathrm{FW})$ and a value of 755 million US\$ in 2015 (Food Agriculture Organization Fisheries and Aquaculture Information and Statistics Branch FAO-FIGIS 2019). This industry directly supports approximately one million farmers and indirectly supports their households, who are often not reported in statistics as workers (Food Agriculture Organization 2016; Badan Pusat Statistik 2017a, b). As the global market demand for this crop increases (Campbell and Hotchkiss 2017), the Indonesian government is active in promoting the sustainable growth of the industry through supportive legislation and policies. Recent additions to legislation include protection and empowerment of farmers (National Legislation Law No. 7/2016), tax-free importation of cultivation equipment (Government Regulation PPRI No.81/2015), provision of a national competency qualification in seaweed processing from the Ministry of Labor (Ministerial Regulation No.107/2016) and new regulations 
for seedling distribution (Ministerial Regulation No.217/PER$\mathrm{DJPB} / 2017$ ). As a result of this government support, seaweed cultivation is now practiced in 31 of the 34 provinces in Indonesia (Badan Pusat Statistik (BPS) 2017a).

Despite the government drive to support and regulate the seaweed industry, growth in production remains limited. One of the major limiting factors is the increase in outbreaks of 'ice-ice' disease and epiphytic pests, which cause a decline in crop quality and lead to total crop loss (Largo et al. 2017; Loureiro et al. 2017; Reddy et al. 2017; Syafitri et al. 2017). In 2000-2001, the region of Kepulauan Seribu reported crop losses by diseases of up to $80 \%$, with Lombok, South Sulawesi and Central Sulawesi reporting a $50 \%$ loss, and Kalimantan and Moluccas a 30\% loss (Ministry of Marine Affair and Fisheries (MMAF-KKP) 2002; Yulianto 2004). This outbreak has since continued and has led to a significant decline in several formerly productive areas in North Sulawesi, North Moluccas, South and East Kalimantan, West Papua and Gorontalo between 2011 and 2015 (Fitrian 2015; Badan Pusat Statistik (BPS) 2017a). In addition to direct loss resulting from disease, the widespread practice of repetitive vegetative propagation has had an impact on seedling vigour, resulting in reduced crop quality, quantity and ability to resist diseases (Dawes et al. 1993; Halling et al. 2013; Yong et al. 2014; Hayashi et al. 2017; Reddy et al. 2017; Hurtado et al. 2019).

The introduction of new species to combat the loss of vigour and the transportation of live seedlings or seed stock is often practiced to support the development of seaweed aquaculture (Bindu and Levine 2011; Valderrama et al. 2015; Hayashi et al. 2017; Hwang et al. 2018; Hurtado et al. 2019). However, these practices are well documented as major pathways for introducing and facilitating the spread of diseases and pests in seaweed aquaculture worldwide (Sulu et al. 2004; Largo et al. 2017; Loureiro et al. 2017; Badis et al. 2019; Ward et al. 2019). For example, the documented infection of Porphyra/Pyropia in Europe and Asia with the pathogenic oomycete Olpidiopsis (Kim et al. 2014; Badis et al. 2019; Ward et al. 2019) and outbreaks of the epiphytic pests Neosiphonia and Polysiphonia spp. in Kappaphycus seedlings are both attributed to trading as a pathway for pest introductions (Hurtado et al. 2019).

To minimize the introduction and spread of disease and pests, the "biosecurity" concept has played an increasingly important role in policy which supports a sustainable aquaculture sector (Bondad-Reantaso et al. 2005; Food Agriculture Organization 2007, 2018; Cottier-Cook et al. 2016; Campbell et al. 2019; Henríquez-Antipa and Carcamo 2019). Biosecurity is linked to many critical production sectors and under its classic definition by the United Nations Food and Agriculture Organization (FAO) is 'a strategic and integrated approach for analyzing and managing relevant risks to human, animal and plant life and health, and associated risks to the environment' (Food Agriculture Organization 2007). Biosecurity measures have been implemented in many aquaculture sectors and are particularly well-established in the food production sectors of countries including the UK, Australia, Canada, the USA and New Zealand and are used to facilitate international trade (Banks et al. 2012; Hine et al. 2012; Rodgers et al. 2015; Stentiford et al. 2017). The inclusion of biosecurity measures in policy and practice, particularly in the seaweed aquaculture industry which is generally concentrated in low to middle-income countries, has lagged behind other sectors, thus leaving the sector vulnerable to disease and pest outbreaks (Cottier-Cook et al. 2016; Henríquez-Antipa and Carcamo 2019). Biosecurity frameworks for the Indonesian aquaculture industry are currently being revised and this is reflected by the inclusion of Indonesia as a pilot country in an FAO program in 2019 to enhance biosecurity capacity in fish aquaculture by the Ministry of Marine Affairs and Fisheries (Ministry of Marine Affair and Fisheries (MMAFKKP) 2019).

Given the current interest, globally and nationally, to enhance awareness and implementation of biosecurity measures, this work is the first evaluation of biosecurity content in Indonesia for the seaweed cultivation sector. Biosecurity content in policy and legislative frameworks is identified and quantitatively analysed, to indicate where deficiencies may exist which can be improved to strengthen the national biosecurity strategy for seaweed cultivation. Developing a national biosecurity strategy is an internationally recognized step to take to minimize the introduction and spread of disease and pests in the aquaculture industry. This analysis identifies specific policy recommendations intended to facilitate the development of a coherent biosecurity strategy in the seaweed industry of Indonesia. By building on this understanding, lateral integration of policy developments with the seaweed industry elsewhere will benefit the industry globally.

\section{Methods}

\section{Selection of biosecurity frameworks}

A number of policies, legislation and regulatory texts related to seaweed aquaculture, either through aquaculture (aquatic plant) or agriculture (plant product), were selected from a variety of sources including: the online government portal (jdih.kkp.go.id), published policy manuals and grey literature from government sources, independent institutions and NGOs. Collectively referred to as frameworks, their relevance to biosecurity was based on the scope of the policy or legislation including elements of the biosecurity principles outlined in the FAO Biosecurity tool kit (Food Agriculture Organization 2007). Where possible, current documents reviewed were published from 1990 to 2018, a period 
in which time seaweed cultivation became well-established in Indonesia.

\section{Systematic analysis of biosecurity frameworks}

The selected frameworks texts were assessed systematically using an adapted methodology from Dahlstrom et al. (2011). Categories of biosecurity themes and risks were identified within the texts and quantified to present detailed inclusion of biosecurity concepts in current frameworks. From this thematic analysis, key gaps were identified for further development of biosecurity content and coherence as part of the national biosecurity strategy for Indonesia.

\section{Thematic analysis}

There were five themes used to analyse the objectives of the frameworks and relevance to seaweed cultivation. The legal force of the framework was classed as either binding or nonbinding. The terminology of seaweed inclusion in the framework was categorized as either seaweed explicit, not seaweed explicit, but with general inclusion under the wider terms of aquaculture and fisheries, and general food security for all production sectors. The biosecurity approaches taken in the framework were classed by the use of penalties, through preventative measures, detection measures, incentives and by response and recovery planning. The information sources used in each of the frameworks was categorized as scientific literature, selective expert opinion, stakeholder opinion, anecdotal reports and experiential evidence. Finally, the adoption of the precautionary principle was categorized as explicit in its use, not explicit but implied precautionary approach and no consideration given. The number of frameworks which fell under each theme and the proportion of those in each category were calculated to give a quantitative overview of the biosecurity frameworks in operation.

\section{Seaweed aquaculture risk analysis}

The impact of biosecurity risks associated with seaweed cultivation were identified in the texts of each framework and quantified to show the proportion of frameworks, which considered each of the risks. Risks were categorized under six main impact areas: direct impacts on the local environment, impacts on ecological interactions between the living organisms and their environment, impacts on the ecosystem processes, impacts on the economics of the farm system and on the social and cultural environment and the welfare of seaweed farm workers. The potential risks associated with disease and pests in each of the categories were then identified in each of the framework texts and quantified as a proportion of all possible texts.

\section{National biosecurity strategy}

Components of the national biosecurity strategies of Indonesia were identified based on their identification in the FAO "Biosecurity Toolkit" (Food Agriculture Organization 2007) and consisted of mechanisms/tools to regulate biosecurity nationally. A total of 16 components were cross-referenced in the selected frameworks to identify where their components were included in policy and legislative texts. The reference to each component in selected frameworks was quantified and the proportion of texts that included the component was calculated.

\section{Results}

Eleven policy and legislation documents were selected as the biosecurity frameworks available for analysis. These documents included three national legislations/laws produced by the parliament/legislator, three government regulations that were issued by the President of the Republic of Indonesia and two ministerial regulations which were issued by the MMAF as the competent authority (CA) for aquaculture and fisheries in Indonesia. A description of each framework and their relevance to aspects of biosecurity in seaweed aquaculture is detailed in Table 1.

\section{Thematic analysis}

Thematic analysis found that the majority (73\%) of biosecurity frameworks were legally binding (i.e. national legislation and government regulations) and the remaining $27 \%$ were nonbinding (i.e. National Indonesian Standards, SNIs). Despite there being some non-binding frameworks, these texts made reference to appropriate national laws or regulations, which were enforced. Only three of the frameworks (27\%) explicitly included the cultivation of seaweeds (i.e. Standar Nasional Indonesia No. 7672/2011, Standar Nasional Indonesia No. 7579/2010 and Standar Nasional Indonesia No. 2690/2015), while the three laws (i.e. Law No. 31/2004, Amendment Law No. 45/2009 and Law No. 16/1992) were non-specific. However, as national guidelines, the three SNIs provided a mechanism for accreditations regarding specific procedures during cultivation (e.g. seedling, planting to grow-out and post-harvest procedures). The majority of the frameworks implicitly included seaweeds, in combination with all other aquaculture activities (64\%), and the rest of the frameworks included seaweeds, as part of the food production sector, under general food security (9\%) (Table 2).

The use of penalties was an approach taken by three of the frameworks (27\%), including the national fisheries law and amendment (Law No. 31/2004 and No. 45/2009) and the national quarantine law (Law No. 16/1992). All of the frameworks included general prevention as an approach to 
Table 1 Selected biosecurity frameworks

\begin{tabular}{|c|c|}
\hline Legislation/regulations & Description \\
\hline \multicolumn{2}{|l|}{ 1. National legislation } \\
\hline $\begin{array}{l}\text { National Fisheries Law } \\
\text { (Law No. 31/2004) }\end{array}$ & $\begin{array}{l}\text { Regulates most aspects of fisheries and aquaculture activities, } \\
\text { including prevention of pests/pathogens/invasive species, } \\
\text { environmental impacts, food safety and food quality, licencing, } \\
\text { zoning and aspects of enforcement }\end{array}$ \\
\hline $\begin{array}{l}\text { Amendment of Fisheries Law No. } \\
\text { 31/2004 (Law No. 45/2009) }\end{array}$ & $\begin{array}{l}\text { Improvement of fisheries regulation; controlling in transport of } \\
\text { aquatic animals, standard quality of fisheries product, water } \\
\text { management in aquaculture and authority, food security } \\
\text { socialization }\end{array}$ \\
\hline $\begin{array}{l}\text { National Quarantine Law } \\
\text { (Law No. 16/1992) }\end{array}$ & $\begin{array}{l}\text { Regulates all matters concerning aquatic and terrestrial, animal and } \\
\text { plant quarantine procedures including the required actions to be } \\
\text { taken in areas that quarantine is required, the type of } \\
\text { pest/pathogen/invasive species to be considered for quarantine, } \\
\text { import and export requirements, and details of enforcement }\end{array}$ \\
\hline \multicolumn{2}{|l|}{ 2. Government regulations } \\
\hline $\begin{array}{l}\text { Fish quarantine regulations (PPRI No. } \\
15 / 2002 \text { ) }\end{array}$ & Fish quarantine protocols regarding pests and pathogens \\
\hline $\begin{array}{l}\text { Aquaculture farm management } \\
\text { regulations (PPRI No. 28/2017) }\end{array}$ & $\begin{array}{l}\text { Regulation of fish cultivation, utilization and preservation of stocks, } \\
\text { management of infrastructure and facilities, product quality } \\
\text { control, environmental impact management, enforcement and } \\
\text { monitoring requirements }\end{array}$ \\
\hline $\begin{array}{l}\text { Regulation of GMO organisms } \\
\text { (PPRI No. 21/2005) }\end{array}$ & $\begin{array}{l}\text { GMO management including research and development of GMO for } \\
\text { cultivation, assessment and utilization of GMO, surveillance and } \\
\text { control of GMO }\end{array}$ \\
\hline \multicolumn{2}{|l|}{ 3. Ministerial regulation } \\
\hline $\begin{array}{l}\text { Food safety regulations } \\
\text { (MMAF-KEP No. 02/MEN/2007) }\end{array}$ & $\begin{array}{l}\text { Provides guidance for fish cultivation with a focus on utilization of } \\
\text { fish for feeds, fertilizer, probiotics and disinfection, relative to } \\
\text { food safety. It also regulates food safety standards post harvest, } \\
\text { distribution and monitoring of the product }\end{array}$ \\
\hline $\begin{array}{l}\text { Fish quarantine requirements } \\
\text { (MMAF-PER No. 10/MEN/2012) }\end{array}$ & $\begin{array}{l}\text { Additional guidance for fish quarantine protocols and requirements } \\
\text { regarding pest, pathogen and invasive species management }\end{array}$ \\
\hline \multicolumn{2}{|l|}{ 4. SNI (Standard National Indonesia) } \\
\hline SNI No. $7672 / 2011$ & $\begin{array}{l}\text { Procedure for seaweed seedling. It consists of seedling requirement } \\
\text { and health checking standard procedure }\end{array}$ \\
\hline SNI No. $7579 / 2010$ & $\begin{array}{l}\text { Procedure for grow-out and planting methods for seaweed that } \\
\text { consists of several applicable planting methods }\end{array}$ \\
\hline SNI No. $2690 / 2015$ & $\begin{array}{l}\text { Post-harvest procedure that consists of several applicable and } \\
\text { recommended methods for drying seaweed }\end{array}$ \\
\hline
\end{tabular}

biosecurity, but the use of detection was only mentioned in $36 \%$ of the frameworks. Incentivization and response and recovery planning were not discussed as an approach. The inclusion of the precautionary principle was explicit in $55 \%$ of the frameworks examined, and the rest had no explicit mention of the principle. The information sources used in the frameworks were predominantly from anecdotal casual reports $(55 \%)$, and scientific literature was used in $27 \%$ of the frameworks (i.e. Standar Nasional Indonesia 2010; Standar Nasional Indonesia 2011; Standar Nasional Indonesia 2015). The use of experiential evidence and both expert and stakeholder opinions were used in $<18 \%$ of the frameworks. Of all the frameworks, the SNI were the most robust in their use of information, from sources including scientific literature, expert and stakeholder opinions and experiential evidence, all in various combinations (Table 2; On-line Appendix 1).

\section{Risk analysis}

Of the eight environmental risks that could be considered in the analysis, direct risks from pests and pathogens were listed in all of the reviewed frameworks, followed by risks from pest and pathogen vectors in $73 \%$ of the frameworks and risks to biodiversity in $55 \%$. The risks of habitat loss or changes, as well as further decreases in already endangered species, were considered in only $27 \%$ of the frameworks (Table 3; On-line Appendix 2). 
Table 2 Summary of thematic analysis of 11 seaweed aquaculture frameworks

\begin{tabular}{ll}
\hline Themes & Total proportional (\%) \\
\hline Force of framework & \\
Binding (B) & $8(73)$ \\
Not binding (NB) & $3(27)$ \\
Terminology for the inclusion of seaweed aquaculture & \\
Seaweed explicit (SE) & $3(27)$ \\
Aquaculture \& fisheries /seaweed not explicit (AgF) & $7(64)$ \\
General food security (FS) & $1(9)$ \\
Biosecurity approach & \\
Penalties (P) & $3(27)$ \\
Prevention (Pr) & $11(100)$ \\
Detection measures (DE) & $4(36)$ \\
Incentives (I) & 0 \\
Response and recovery planning (RRP) & 0 \\
Information source type & \\
Scientific literature (Sci) & $3(27)$ \\
Expert opinion (Exp) & $2(18)$ \\
Stakeholder opinion (Stk) & $1(9)$ \\
Anecdotal report (An) & $6(55)$ \\
Experiential evidence (ExB) & $2(18)$ \\
Use of the precaution principle & \\
Yes explicit (Y) & $6(55)$ \\
Not explicit (NE) & $5(45)$ \\
\hline
\end{tabular}

Others biosecurity risks considered under impacts on ecological interaction, economy and the seaweed industry, social and cultural aspects and the welfare of seaweed farmers were considered in fewer frameworks and inclusion of risks in these categories ranged from 9 to $36 \%$ (see Table 3 ). Risks considered under the ecosystem process category were not included in any of the analysed frameworks. In the ecological interaction category, risks associated with predation and hybridization were included in only $18 \%$ of the reviewed frameworks. In the economic and welfare categories, risks through trade losses, trade restrictions, tourism, shipping, other aquaculture activities, health care costs and food safety were not included in regulations regarding biosecurity (Table 3 ).

\section{National biosecurity components}

Components of the national biosecurity framework for Indonesia were identified in each of the frameworks (Table 4). This assessment identified that multiple authorities are currently involved in national biosecurity regulation. Specific components that were identified to have low inclusion across the frameworks ( 9 to $18 \%$ ) included frameworks for inspecting and certifying aquaculture operations, disinfection procedures, phytosanitary measures, pathogen control, statutory contingency plans, stocking density and disease surveillance regulations (Table 4; On-line Appendix 3).
Some components were included in a much higher proportion of frameworks $(55 \%)$, including those related to concerning introduction of new seaweed stocks and movement of various seaweed species between farms. The components regarding quarantine measures for importing aquatic organisms were not discussed in any of the frameworks. Despite the inclusion of many components, most were not included as regulatory tools (see in Table 4).

\section{Discussion}

This study highlights the lack of legislation and policies which address biosecurity-related issues currently facing the seaweed industry in Indonesia. Specific gaps and deficiencies identified by this analysis are discussed below and recommendations are provided to address these gaps and to indicate where the existing frameworks may be strengthened or developed in the future.

\section{Unspecific allocation of seaweed aquaculture in biosecurity frameworks}

The biggest challenge for developing biosecurity capacity in the national strategy for the seaweed aquaculture sector is the generalization and grouping of the seaweed industry within 
Table 3 Risks regarding biosecurity included in frameworks

\begin{tabular}{|c|c|}
\hline Risks & $\begin{array}{l}\text { Number of frameworks including risk } \\
\text { (\% of frameworks) }\end{array}$ \\
\hline \multicolumn{2}{|l|}{ Local environment } \\
\hline Pest/pathogen & $11(100)$ \\
\hline Pest/pathogen vector & $8(73)$ \\
\hline Biodiversity & $6(55)$ \\
\hline Habitat loss/changed & $3(27)$ \\
\hline Decreased in native species abundance & $5(45)$ \\
\hline Decreased in threatened/endangered species & $3(27)$ \\
\hline Toxicity & $4(36)$ \\
\hline Introduction of new host species for pest/pathogen & $5(45)$ \\
\hline \multicolumn{2}{|l|}{ Ecological interactions } \\
\hline Predation & $3(18)$ \\
\hline Herbivore & $3(18)$ \\
\hline Competition & $3(18)$ \\
\hline Hybridization of commercial and wild & $3(18)$ \\
\hline \multicolumn{2}{|l|}{ Ecosystem processes } \\
\hline Nutrient regime change & 0 \\
\hline Hydrological changes & 0 \\
\hline Food web changes & 0 \\
\hline Physical disturbance & 0 \\
\hline Effect control measurement & 0 \\
\hline Effect of climate change on pest/pathogen/non-native sp. & 0 \\
\hline Production & 0 \\
\hline \multicolumn{2}{|l|}{ Economic on farm system } \\
\hline Infrastructure/facilities/property & $2(18)$ \\
\hline Control and management cost & $4(36)$ \\
\hline Trade loses/loss & $2(18)$ \\
\hline Trade restriction & 0 \\
\hline Adverse consumer/buyer reaction & 0 \\
\hline Tourism & $2(18)$ \\
\hline Shipping (include vessel/waterways) & $1(9)$ \\
\hline Fisheries & 0 \\
\hline Aquaculture/other than seaweed & 0 \\
\hline Restoration/replanting cost to farm & 0 \\
\hline Health care cost & 0 \\
\hline Ecosystem services & 0 \\
\hline Food safety & $1(9)$ \\
\hline \multicolumn{2}{|l|}{ Social and cultural environment } \\
\hline Important social economic, site, person & $3(27)$ \\
\hline \multicolumn{2}{|l|}{ The welfare of seaweed farm workers } \\
\hline Communication of biosecurity risk & $1(9)$ \\
\hline Lost income & 0 \\
\hline Working with infected crop & 0 \\
\hline
\end{tabular}

the fisheries and aquatic animal industries frameworks. This makes implementation of biosecurity measures unclear, particularly regarding disease and pest management (Ward et al. 2019). Current legislation, regarding quarantine protocols and the maintenance of healthy aquaculture systems, was typically directed towards fish and other aquatic animals, despite it being assumed that this legislation also included seaweed cultivation. Many international regulations regarding biosecurity also combine seaweeds with fish and other aquatic animals, such as the FAO, Network of Aquaculture Centre in Asia- 
Table 4 Summary of national biosecurity components included in frameworks
Components/sub-components

Total proportional $(\%)$

Established aquatic animal or plant health regulation

Yes (Y)

$3(27)$

No $(\mathrm{N})$

8 (73)

Component authority responsible for implementing existing regulation

One authority (OA)

Multiple authority (MO)

System for reportable/notifiable diseases

Established system (ES)

System with a list of reportable diseases (SRD)

0

No system (NS)

System for inspecting and certifying aquaculture operation

Yes (Y)

No $(\mathrm{N})$

Import regulation related to diseases

Yes (Y)

No $(\mathrm{N})$

Regulation concerning introduction of new (exotic) seaweed

Regulation no quarantine (RNO)

Regulation on non-natives (RNN)

$4(36)$

No regulation (NR)

Regulation on transport or movement of seaweed

Yes (Y)

No $(\mathrm{N})$

Established disinfection procedures

Yes (Y)

No $(\mathrm{N})$

Other sanitary pathogen control measures

Developed additional procedures (DAP)

No sanitary procedures (NSP)

Statutory contingency plan in place in the event of an outbreak

Yes (Y)

No $(\mathrm{N})$

Seaweed surveillance diagnostic, etc., personal training capabilities

Country training $(\mathrm{CT})$

Other training $(\mathrm{OT})$

0

No training $(\mathrm{NO})$

Regulation regarding seaweed aquaculture site selection for minimizing disease spread

Yes (Y)

No $(\mathrm{N})$

Regulation concerning stocking density

Yes (Y)

No $(\mathrm{N})$

Regular disease surveillance

Yes (Y)

No $(\mathrm{N})$

Quarantine measure establish for imported aquatic animals

0

Introduction of crop cycle separation of seaweed crop as a management principal
0 
Pacific (NACA) and in the National Agro-Food Policy of Malaysia. This, however, compounds the problems of implementing biosecurity-related measures, as the cultivation systems, as well as the physiology of seaweeds are distinctly different to those of fish and other aquatic animals.

As autotrophs, seaweeds have an extractive energetic photosynthetic process, where inorganic nutrients are extracted from the water column (e.g. nitrogen and phosphorus). In comparison, cultivated fish and other aquatic animals generally produce waste nutrients (inorganic or organic) which, in excess, cause deterioration of the local marine environment (Troell et al. 1999; Chopin 2011; Granada et al. 2016; Kambey and Chung 2016). Therefore, the cultivation systems differ greatly as seaweeds do not require the input of commercial feeds which can also include additives such as probiotics, vaccines and other medicinal chemicals, which are regularly used to manage biosecurity risks (Supriyadi and Rukyani 2000; Burridge et al. 2010; Rico et al. 2012; Granada et al. 2016). In addition, the various types of cultivation systems used for seaweeds, such as hanging longlines and off-bottom culture for the red seaweeds Kappaphycus and Eucheuma (Standar Nasional Indonesia 2010; Hayashi et al. 2017), hanging rafts and nets for Saccharina, Gracilaria and Porphyra (Yang et al. 2015; Peteiro et al. 2016; Kim et al. 2017; Stevant et al. 2017) are also different to many other aquatic animal cultivation systems.

Cultivation of Kappaphycus and Eucheuma is also characterized by a short, single crop cycle of 35-45 days (Standar Nasional Indonesia 2010; Neish 2013), compared to many fish species which may take months to years (Hutapea et al. 2017; Suwirya and Giri 2018). Disease and pest outbreaks can, therefore, develop far more rapidly (Largo et al. 1995, 2017; Syafitri et al. 2017) compared with fish and aquatic animals (Flegel 2012; Brazenor and Hutson 2015). This example should be taken into account in quarantine measures where a 14-day quarantine period has been suggested as appropriate for seaweeds (Zemke-White and Smith 2006; Food Agriculture Organization 2007; Malaysian Standard 2012) compared with a recommended isolation period of 21 days or longer for fish (Whittington and Chong 2007; Hadfield and Clayton 2011; Becker et al. 2014). Based on these differences, amongst others, it is recommended that the management of seaweed cultivation systems should be considered separately to fish and other aquatic animals.

In addition to the physiological characteristics of seaweeds, another reason for the lack of inclusion of the seaweed industry in national policy and legislation is due to the perception that seaweed is a low-value component of the aquaculture and fisheries sector. For example, seaweed production in 2015 accounted for approximately 10.1 million tonnes fresh weight (FW) or $70 \%$ of the national aquaculture production compared with shrimp production at only 161,000 tonnes FW (Badan Pusat Statistik (BPS) 2017a; Food Agriculture Organization
2018; Food Agriculture Organization Fisheries and Aquaculture Information and Statistics Branch FAO-FIQIS 2019). However, the economic contribution of shrimp production to the national aquaculture sector reached 2.2 billion US\$, while the value of seaweed was only 775 million US\$ in 2015 (Badan Pusat Statistik (BPS) 2017a; California Environment Association 2018; Food Agriculture Organization 2018; Food Agriculture Organization Fisheries and Aquaculture Information and Statistics Branch FAO-FIQIS 2019). Seaweed production is, therefore, a relatively small contributor to the overall value of the combined aquaculture and fisheries sectors in Indonesia; however, they provide significant income to many rural farmers and their families (Food Agriculture Organization 2016; Badan Pusat Statistik (BPS) $2017 \mathrm{a}, \mathrm{b}$ ). The seaweed industry also supports regional economic resilience and improves the living standards for middleincome communities (Neish et al. 2017; Marino et al. 2019). Ecologically, seaweed farms can also provide ecosystem services, such as carbon capture, primary production and provision of additional habitats (Sondak et al. 2017; Hasselstrom et al. 2018; Froehlich et al. 2019). Therefore, the potential for growth in the seaweed industry has been recognized in a recent policy road map produced by MMAF through Ministerial Regulation 2015, which aimed to enhance cultivation and processing in 2014-2019. It is important, therefore, to adapt, specifically include or develop separate biosecurity frameworks in Indonesia to enable this industry to grow. In addition, it is essential to recognize that the implementation of aquatic animal management measures may be ineffective in the seaweed industry in limiting the occurrence of disease and pests.

\section{Limited variety of biosecurity approaches}

The current Indonesian biosecurity strategy predominantly takes a preventative approach to management measures for diseases or pests, such as invasive species. Although prevention is an important biosecurity component, using only this approach will not prevent all outbreaks. The preventative approach is found in frameworks, which include quarantine procedures for controlling diseases, as part of the health checking procedure required to transport seaweed across regions, along with fish and other aquatic animals (Law No. 16/1992 and PER No. 10/MEN/2012). The fact, national quarantine process does not include for life seaweed neither for national trading nor for importation because lack of appropriate facilities and no clear regulation for seaweed quarantine process (R. Mustafa, Fisheries Officer at Dinas Kelautan dan Perikanan DKP, personal communication). The regular monitoring of seedling health status, traceability and the maintenance of a clean farm environment are also additional preventative measures that could help control diseases, such as 'iceice' (Marino et al. 2019; Ward et al. 2019). These measures are regularly applied in other aquaculture systems (Rodgers et al. 
2015; Jia et al. 2017; Stentiford et al. 2017). To date, seaweed farmers in Indonesia prevent disease and pest outbreaks on their farm using personal observational detection methods, unsupported by scientific knowledge or standardized guidelines (Marino et al. 2019).

Incentivization of biosecurity-related measures in seaweed aquaculture or any national aquaculture system was not discussed in any of the reviewed frameworks. An incentivized approach can motivate farmers to adopt improved farming practices (e.g. the Nutrient Trading Credit program by Chopin 2011), but this approach requires resources for which there may be limited capacity either in the governmental or industrial sectors. To date, funding aid from the national government through their subsidy program is a reliable and applicable incentives approach (e.g. subsidy for seedlings in MMAF No. 217/PER-DJB/2018). However, this program lacks regulatory control, which has led to unsuccessful implementation of this approach in many seaweed producing areas and has created a barrier for the further adoption of such an approach to decentralizing biosecurity management. Building awareness through appropriate penalties, and incentives or subsidized approaches, properly managed by either the national or regional competent authority therefore will be important in improving farming practices (Cottier-Cook et al. 2016; Jia et al. 2017; Henríquez-Antipa and Carcamo 2019). In addition, it may be possible to adopt the biosecurity program into a national biosecurity framework, which is internationally recognized, based on a country's ability to trade a cultured product, which is free from specific diseases and pathogens (Hastein et al. 2008).

Detection of diseases through standardized diagnostic techniques such as histopathology and DNA markers can help with earlier identification of the symptoms of a microbial pathogen and aid in the understanding of factors, which cause disease outbreaks (Ward et al. 2019). Current detection measures in national biosecurity frameworks include some diagnostic techniques and provision of a notifiable list of wild, cultured and invasive fish pests and pathogens (PPRI No. 15/2002; MMAF-PER No. 10/MEN/2010). However, the application of such diagnostic techniques (included in national quarantine regulations) are only applicable to fish and other aquatic animals. A range of approaches is also recommended to promote implementation including background monitoring of endemic diseases and disease outbreak recovery plans to enforce the implementation (Payne et al. 2014; Loureiro et al. 2015; Cottier-Cook et al. 2016). Although there are many factors which influence what, when and how a pathogen can be detected, the industries which have invested heavily in detection have maintained profitable levels of production where disease had been a limitation (Thitamadee et al. 2016; Stentiford et al. 2017). Current frameworks were also found to be outdated (Law No. 16/1992 and Law No. 31/2004, 45/ 2009) and simple methods such as monitoring the health status of seaweed crop by an assigned competent authority is not undertaken as there is no clear regulation which requires it.
Therefore, the occurrence of disease and pest outbreaks remains unmonitored and is unpredictable to manage. Integrating a variety of approaches to biosecurity in a national strategy will, therefore, enable the industry to be more resilient to environmental and societal changes and to implement more adaptive management strategies.

\section{Limited scientific information in seaweed framework}

Adopting evidence-based policies is viewed as necessary for developing the most up-to-date approaches to biosecurity (Scarfe 2003; Dahlstrom et al. 2011; Loureiro et al. 2015; Rodgers et al. 2015). Despite numerous studies on seaweed pests and diseases in Indonesia (Yulianto 2004; Fitrian 2015; Syafitri et al. 2017), most of the information used to inform biosecurity in national policy and legislation is from anecdotal reports. Only five of the 11 Indonesian frameworks assessed mentioned the use of scientific literature, experiential evidence and expert or stakeholder opinions, which are a critical requirement for building robust national regulations. As a consequence, relevant frameworks for the seaweed industry remain uninformed by scientific information regarding pests, diseases and appropriate biosecurity measures and are, therefore, based on a high level of uncertainty.

\section{Limited guidance for the use of precautionary principle}

Managing biosecurity in the face of emerging and unidentified pests and diseases requires a degree of precaution. The precautionary principle has become a key element for policy decisions concerning conservation management (CostaPierce and Page 2010; Sampaio et al. 2015). This concept is transferable to the sustainable management of aquaculture (Troell et al. 1999; Morton and Routledge 2016; Kirkpatrick et al. 2019). To be effective in biosecurity frameworks, precaution should be specific to what is being prevented and to the risk (Sampaio et al. 2015).

Various precautionary principles were found in almost all Indonesian biosecurity frameworks such as preventing disease outbreaks through import or transport of live aquatic animals (PER No. 10/MEN/2012, No. 15/MEN/2002), preventing the risk of introduction of invasive cultured species, which may impact the environment and native populations (Law No. 16/ 1992, PPRI No. 28/2017), and preventing the release of GMO's into the environment, which may have an impact on the health of humans and animals (PPRI No. 21/2005). The precautionary approach should be supported by an evidence base from both scientific research and experiential evidence (Sampaio et al. 2015). Because there is insufficient scientific and experiential evidence information used in the biosecurity frameworks analysed, precaution was often unspecific. For example, the quarantine regulations of PER No. 15/MEN/ 
2002 and 10/MEN/2012 aim to prevent the risk of diseases, but there are no protocols outlined for how this should be done and who is responsible as the competent authority. The decreasing of seaweed Kappaphycus and Eucheuma diversity and seedling quality in Indonesia become evidence for no farming precautionary approach; therefore, the spread of cultivated species through vegetative practices has been widely observed in seaweed growing regions (Halling et al. 2013), even though there was a possibility to improve the quality of disease resistance of seaweed cultured by domestication of wild Kappaphycus and Eucheuma species (Lim et al. 2013).

Although it is a well-known effective measure to integrate the precautionary principle into aquaculture through the risk assessment process (Sethi 2010; Morton and Routledge 2016), risks at the farm level still remain unclear because of a lack of evidence for risk identification and their consequences. Some production areas in Indonesia have reported declines in regional production (Badan Pusat Statistik (BPS) 2017a). For example, the Bengkulu Province saw a dramatic decrease in production per unit area of $99.59 \%$ in 2015 compared to 2011, and South Kalimantan, Bangka Belitung, Gorontalo and North Maluku also decreased by 80.1, 76.0, 58.8 and $36 \%$, respectively. On the other hand, in the central productive areas of South Sulawesi and East Nusa Tenggara, production has increased more than $200 \%$, although this is largely due to recent expansion of cultivation in these regions. At the same time, the Papua province saw an $84 \%$ decrease in production in 2014 and then an increase of about $80 \%$ through expansion of new cultivation areas the following year (BPS Statistics 2017a). This pattern of decreased production in areas where seaweed cultivation has been well-established and the increases in production by expanding into new areas under regulations which are lacking in precautionary measures risks further spread and establishment of diseases and pests. This type of expansion, combined with poor availability of healthy seedling/crops may have a significant impact on future national production.

\section{Insufficient evidence of biosecurity hazards in seaweed aquaculture}

In order to address the risks posed by diseases and pests in seaweed aquaculture, biosecurity frameworks should take into account evidence on the nature of their occurrence, in order to manage the risks. The risk from pests and disease are one of the most prominent natural environment risks found in the Indonesian fisheries and aquaculture frameworks analysed. However, the inclusion of the risk is often not supported with methods or protocols for assessing, managing and communicating the risk, as has been suggested for the aquaculture industry in order to improve biosecurity (Hewitt and Campbell 2008; Phillips and Subasinghe 2008; Campbell et al. 2019).

The risk with most detailed management measures was the movement of seaweed crops. This movement can transfer pests and diseases from one cultivation area to another and is also one of the most studied aspects of disease in seaweed aquaculture (Largo et al. 2017; Loureiro et al. 2017; Ingle et al. 2018; Ward et al. 2019). Evidence for this risk includes documented competition between Kappaphycus spp. and Eucheuma sp. with coral reefs in Hawaii and India (Sulu et al. 2004; Zemke-White and Smith 2006; Kamalakannan et al. 2014) and degradation of seagrass meadows resulting in decreased seagrass populations in Indonesia (Thomsen et al. 2012; Unsworth et al. 2018). Such evidence indicates that cultivated seaweed species can be highly competitive and opportunistic, with high growth rates and adaptability in tropical environments (Zuccarello et al. 2006; Conklin et al. 2009; Kamalakannan et al. 2014; Tano et al. 2015; Largo et al. 2017). The risk of introducing invasive species and of reducing genetic diversity through cultivation was included in fewer frameworks. Rather than following recommendations to develop a strong evidence base to manage pests and diseases and improve culture methods through specific studies on disease management (Bondad-Reantaso et al. 2005; Marino et al. 2019), policy efforts are also currently focused on expanding cultivation into new areas in Indonesia. Internationally, further research of disease and pest risks in seaweed cultivation is recommended (Halling et al. 2013; Lim et al. 2013; Payne et al. 2014; Dijkstra et al. 2017; Badis et al. 2019; Campbell et al. 2019; Campbell et al. 2019; Ward et al. 2019) and should be included in biosecurity frameworks to support the national biosecurity strategy (Cottier-Cook et al. 2016).

\section{National biosecurity components}

Given the lack of seaweed-specific biosecurity measures in policy and regulation in Indonesia, there is huge potential for biosecurity risks to be reduced in the seaweed industry through better management. However, current components of national biosecurity frameworks identified in this analysis show inconsistent use of the biosecurity concept. For instance, disease management was described separately as both pest control and cleaning (MMAF-KEP No. 02/MEN/2007; World Wide Fund for Nature 2014; Standar Nasional Indonesia 2016). The quarantine regulations lack any health monitoring procedures and management of invasive species for seaweeds, and there is no formal isolation time mentioned for seaweeds, unlike Malaysian national regulations that require 14-day isolation periods for cultivated seaweeds (Malaysian Standard No. 2467/2012). At present, crop health monitoring requirements are covered by Indonesian lawsNo. 31/2004, 45/2009, and 16/1992 - and require farmers to implement control measures for outbreaks of OIE World Organisation for Animal Health listed diseases, a list which does not include aquatic plants. Unlike other aquaculture sectors, seaweeds have only recently been adopted by the International Plant Protection Convention (IPPC), to manage 
and communicate biosecurity risks internationally (Campbell et al. 2019). The competent authority in Indonesia is the MMAF who are responsible for implementing biosecurity, which is included in many of their regulations concerning biosecurity and seaweed cultivation. The MMAF transfer their governmental powers to regional departments, in order to decentralize the regulation of fisheries and aquaculture, which has raised issues regarding effectiveness of this process (Neish 2013). Another potential limitation is the lack of capacity and political strength of the competent authority to develop and impose the regulations in an industry, which can be resistance to government intervention. Therefore, without a clear mandate for disease and pest monitoring, the development of this component to national biosecurity is hampered.

Even though almost all of the activities regarding seaweed aquaculture are conducted by the farmers, their involvement in developing biosecurity regulations appears limited. Farmers make management decisions based on their own valuable experience-based knowledge, but without consensus in farming areas, management measures can be inconsistent (Ritter et al. 2017; Jia et al. 2017; Marino et al. 2019). Therefore, farmers should be involved in any further development of biosecurity frameworks (Brugere et al. 2016). In return, farmers should be given access to knowledge on diseases and their causative agent (e.g. symptom identification and what might cause disease) and up-to-date information on the best measures to prevent and minimize the onset of a disease outbreak (e.g. systems for reportable/notifiable diseases and disease surveillance). Given the issues of miscommunication between national and regional governments, it is suggested that farmers may benefit from establishing groups (Nor et al. 2017), or utilizing associations (e.g. Indonesian Seaweed Association ARLI or ASTRULI), so they can communicate and share the information regarding cultivation challenges and receive updates on innovations and related actions to mitigate for disease and pest outbreaks (Neish 2013; Neish et al. 2017). In 2014, the World Wildlife Fund (WWF) took proactive action and published better management practices (BMP) together collaborated with local seaweed farmers in promoting sustainable fisheries and responsible aquaculture for supporting the SNI initiative (Nor et al. 2017). Collaborations between academia, government and industry to share information are also crucial to building biosecurity capacity amongst the Indonesian seaweed community.

\section{Conclusions and recommendations}

This analysis provides an overview of the current national biosecurity strategy regarding the seaweed industry of Indonesia. Given the significance of the industry to national aquaculture exports, policies to safeguard the industry from major losses to pests and disease are fragmented and often contradictory. With ongoing support from the central government to grow the seaweed industry of Indonesia and expand cultivation into new regions, improving existing frameworks will be key to sustaining the future growth of this industry. Based on this analysis, six key policy recommendations are provided to enhance national biosecurity frameworks for the seaweed industry:

1. Support further research to develop a strong evidence base, upon which national strategic decisions can be made on the management of the sector.

2. Establish seaweed-specific regulations and policies, providing appropriate management strategies that can be effectively enforced.

3. Establish a national database reporting what species of seaweeds are being produced and where any pest and disease outbreaks occur. This should be followed up with regular evaluation, so that the risks can be assessed by national government and each district, where possible.

4. Support for farmers to invest in the biosecurity management of seaweed cultivation systems including health monitoring equipment, training on management procedures, regional facilities for farmers to use for quarantine of seedlings or crop stock and surveillance systems.

5. Development of a risk assessment procedure for the expansion of farms into new and diseases-free areas.

6. Clarification on who the competent authority will be to regulate and support the seaweed industry.

Acknowledgements The authors would like to acknowledge Prof. Ik Kyo Chung (Pusan National University) and Indonesian Fisheries Officer DKP Gorontalo and BPBL Maros for sharing information regarding seaweed farming practices.

Funding information Funding Information This work was part of the GlobalSeaweedSTAR project supported by the Global Challenge Research Fund (GCRF) Biotechnology and Biological Sciences Research Council Grant 2007 No. BB/P027806/1 and No. IF015-2019.

Open Access This article is licensed under a Creative Commons Attribution 4.0 International License, which permits use, sharing, adaptation, distribution and reproduction in any medium or format, as long as you give appropriate credit to the original author(s) and the source, provide a link to the Creative Commons licence, and indicate if changes were made. The images or other third party material in this article are included in the article's Creative Commons licence, unless indicated otherwise in a credit line to the material. If material is not included in the article's Creative Commons licence and your intended use is not permitted by statutory regulation or exceeds the permitted use, you will need to obtain permission directly from the copyright holder. To view a copy of this licence, visit http://creativecommons.org/licenses/by/4.0/.

\section{References}

Badan Pusat Statistik (BPS) Statistics Indonesia (2017a) Statistics of marine and coastal resources. Badan Pusat Statistik Press, Jakarta. 708 pp

Badan Pusat Statistik (BPS) Statistics Indonesia (2017b) Statistical yearbook of Indonesia. Badan Pusat Statistik Press, Jakarta. 310 pp 
Badis Y, Klochkova TA, Strittmatter M, Garvetto A, Murua P, Sanderson JC, Kim GH, Gachon CMM (2019) Novel species of the oomycete Olpidiopsis potentially threaten European red algal cultivation. J Appl Phycol 31:1239-1250

Banks J, Lem A, Young JA, Yagi N, Guttormsen A, Filose J, Gautier D, Reardon T, Palmer R, Rad F, Anderson J, Franz N (2012) Facilitating market access for producers: addressing market access requirements, evolving consumer needs, and trends in product development and distribution. In: Subasinghe RP, Arthur JR, Bartley DM, De Silva SS, Halwart M, Hishamunda N, Mohan CV, Sorgeloos P (ed) Farming the waters for people and food. Proceedings of the Global Conference on Aquaculture 2010, Phuket, Thailand. 22-25 September 2010. FAO Rome and NACA, Bangkok, pp 495-524

Becker JA, Tweedie A, Rimmer A, Landos M, Lintermans M, Whittington RJ (2014) Incursion of Cyprinid herpesvirus 2 in goldfish population in Australia despite quarantine practices. Aquaculture 432:53-59

Bindu MS, Levine IA (2011) The commercial red seaweed Kappaphycus alvarezii- an overview on farming and environment. J Appl Phycol 23:789-796

Bondad-Reantaso MG, Subasinghe RP, Arthur JR, Ogawa K, Chinabut S, Adlard R, Tan Z, Shariff M (2005) Disease and health management in Asian aquaculture. Vet Parasitol 132:249-272

Brazenor AK, Hutson KS (2015) Effects of temperature and salinity on the life cycle of Neobenedenia sp. (Monogenea: Capsalidae) infecting farmed barramundi (Lates calcarifer). Parasitol Res 114:1875-1886

Brugere C, Onuigbo DM, Morgan KL (2016) People matter in animal disease surveillance: challenges and opportunities for the aquaculture sector. Aquaculture 467:158-169

Burridge L, Weis J, Cabello F, Pizarro J (2010) Chemical used in salmon aquaculture: a reviewed of current practices and possible environment effect. Aquaculture 306:7-23

California Environment Association (2018) Trends in marine resources and fisheries management in Indonesia: a review. Annual report. The David Lucile and Packard Foundation Press, California, pp 1-146

Campbell R, Hotchkiss S (2017) Carrageenan industry market overviewed. In: Hurtado AQ, Chritchley AT, Neish IC (eds) Tropical seaweed farming trends, problems and opportunities: focus on Kappaphycus and Eucheuma. Springer, Cham, pp 121-129

Campbell I, Macleod A, Sahlmann C, Neves L, Funderud J, Overland M, Hughes AD, Stanley M (2019) The environmental risks associated with the development of seaweed farming in Europe-prioritizing key knowledge gaps. Front Mar Sci 6:1-22

Chopin T (2011) Progression of the integrated multi-trophic aquaculture (IMTA) concept and upscaling of IMTA systems towards commercialization. Aqua Europe 36:5-12

Conklin KY, Kurihara A, Sherwood AR (2009) A molecular methods for identification of the morphologically plastic invasive algal genera Eucheuma and Kappaphycus (Rhodophyta, Gigartinales) in Hawaii. J Appl Phycol 21:691-699

Costa-Pierce BA, Page GG (2010) Sustainability science in aquaculture. In: Costa-Pierce BA (ed) Ocean farming and sustainable aquaculture science and technology. Encyclopedia of sustainability science and technology. Springer Science, NY, pp 1-28

Cottier-Cook EJ, Nagabhatla N, Badis Y, Campbell M, Chopin T, Dai W, Fang J, He P, Hewitt C, Kim GH, Huo Y, Jiang Z, Kema G, Li X, Liu F, Liu H, Lu Q, Luo Q, Mao Y, Msuya FE, Reboursc, Shen H, Stentiford GD, Yarish C, Wu H, Yang Z, Zhang J, Zhou Y, Gachon CMM (2016) Safeguarding the future of the global seaweed aquaculture industry. United National University (INWEH) and Scottish Association for Marine Science Policy Brief. ISBN 97892-808-6080 pp 1-12

Dahlstrom A, Hewitt CL, Campbell ML (2011) A review of international, regional and national biosecurity risk assessment framework. Mar Policy 35:208-217
Dawes CJ, Trono GC Jr, Lluisma AO (1993) Clonal propagation of Eucheuma denticulatum and Kappaphycus alvarezii for Philippine seaweed farms. Hydrobiologia 261:379-383

Dijkstra JA, Harris LG, Mello K, Litterer A, Wells C, ware C (2017) Invasive seaweed transform habitat structure and increase biodiversity of associated species. J Ecol 105: 1668-1678

Fitrian T (2015) Hama penyakit (ice-ice) pada budidaya rumput laut studi kasus Maluku Tenggara. Oseana 4:1-10

Flegel TW (2012) Historic emergence, impact and current status of shrimp pathogens in Asia. J Invertebr Pathol 110:166-173

Food Agriculture Organization (2007) FAO biosecurity toolkit. The United Nations. Rome. $140 \mathrm{pp}$

Food Agriculture Organization (2016) The state of world fisheries and aquaculture. Contributing to food security and nutrition for all. Rome. $200 \mathrm{pp}$

Food Agriculture Organization (2018) The global status of seaweed production, trade and utilization. Vol 124 FAO Consultants Products, Trade and Marketing Branch Fisheries and Aquaculture Policy and Resources Division, Rome, 120 pp

Food Agriculture Organization Fisheries and Aquaculture Information and Statistics Branch FAO-FIGIS (2019) FIGIS-Time series query on Aquaculture. Retrieved from http://www.fao.org/figis/servlet/ SQservlet.htm on 26 July 2019

Froehlich HE, Afflerbach JC, Frazier M, Halpern BS (2019) Blue growth potential to mitigate climate change through seaweed offsetting. Curr Biol 29:1-7

Government Regulation: Peraturan Pemerintah Republik Indonesia No 15 tahun 2002. Karantina Ikan. Jakarta, pp 1-37

Government Regulation: Peraturan Pemerintah Republik Indonesia No 21 tahun 2005. Keamanan hayati produk rekayasa genetik. Jakarta, pp 1-39

Government Regulation: Peraturan Pemerintah Republik Indonesia No 81 tahun 2015. Impor dan atau penyerahan barang kena pajak tertentu yang bersifat strategis dan dibebaskan dari pengenaan pajak pertambahan nilai. Jakarta, pp 1-9

Government Regulation: Peraturan Pemerintah Republik Indonesia No 28 tahun 2017. Pembudidayaan ikan. Jakarta, pp 1-44

Granada L, Sousa N, Lopes S, Lemos MFL (2016) Is integrated multitrophic aquaculture the solution to the sector's major challenges? A review. Rev Aquac 8:283-300

Hadfield CA, Clayton LA (2011) Fish quarantine: current practices in public zoos and aquaria. J Zoo Wildlife Med 42:641-650

Halling C, Wikstrom SA, Lillieskold-Sjoo G, Mork E, Lundsor E, Zuccarello GC (2013) Introduction of Asian strains and low genetic variation in farmed seaweeds: indications for new management practices. J Appl Phycol 25:89-95

Hasselstrom L, Visch W, Grondahl F, Nylund GM, Pavia H (2018) The impact of seaweed cultivation on ecosystem service - a case study from the west coast of Sweden. Mar Pollut Bull 133:53-64

Hastein T, Binde M, Hine M, Johnsen S, Lillehaug A, Olesen NJ, Purvis N, Scarfe AD, Wright B (2008) National biosecurity approaches, plans and programs in response to diseases in farmed aquatic animals: evolution, effectiveness and the way forward. Rev Sci Tech Off Int Epiz 27:125-145

Hayashi L, Reis RP, dos Santos AA, Castelar B, Robledo D, de Vega GB, Msuya FE, Eswaran K, Yasir SM, Ali MKM, Hurtado AQ (2017) The cultivation of Kappaphycus and Eucheuma in tropical and subtropical waters. In: Hurtado AQ, Chritchley AT, Neish IC (eds) Tropical seaweed farming trends, problems and opportunities: focus on Kappaphycus and Eucheuma. Springer, Cham, pp 55-90

Henríquez-Antipa LA, Carcamo F (2019) Stakeholder's multidimensional perceptions on policy implementation gaps regarding the current status of Chilean small-scale seaweed aquaculture. Mar Policy 103:138-147

Hewitt C, Campbell M (2008) Assessment of relative contribution of vectors to the introduction and translocation on marine invasive species. Report for the Department of Agriculture, Fisheries and Forestry. University of Tasmania, Hobart. Contract report 
Hine M, Adams S, Arthur JR, Bartley D, Bondad-Reantaso MG, Chávez C, Clausen JH, Dalsgaard A, Flegel T, Gudding R, Hallerman E, Hewitt C, Karunasagar I, Madsen H, Mohan CV, Murrell D, Perera R, Smith P, Subasinghe R, Phan PT,Wardle R (2012) Improving biosecurity: a necessity for aquaculture sustainability. In: Subasinghe RP, Arthur JR, Bartley DM, De Silva SS, Halwart M, Hishamunda N, Mohan CV, Sorgeloos P. (ed) Farming the waters for people and food. Proceedings of the global conference on aquaculture 2010, Phuket, Thailand. 22-25 September 2010. FAO, Rome and NACA, Bangkok, pp 437-494

Hurtado AQ, Lim PE, Tan J, Phang SM, Neish IC, Critchley AT (2016) Biodiversity and biogeography of commercial tropical carrageenophytes in the southeast Asian region. In: Pereira L (ed) Carrageenans: sources and extraction methods, molecular structure, bioactive properties and health effects. Nova Science, Hauppauge, pp 67-90

Hurtado AQ, Neish IC, Critchley AT (2019) Phyconomy: the extensive cultivation of seaweeds, their sustainability and economic value, with particular reference to important lessons to be learned and transferred from the practice of eucheumatoid farming. Phycologia 58:472-483

Hutapea JH, Setiadi A, Gunawan G, Permana IGN (2017) Performa pemijahan ikan tuna sirip kuning, Thunnus albacores di karamba jaring apung. J Riset Akua 12:49-56

Hwang EK, Liu F, Lee KH, Ha DS, Park CS (2018) Comparison of the cultivation performance between Korean (Sugwawon No. 301) and Chinese strains (Huangguan No. 1) of kelp Saccharina japonica in an aquaculture farm in Korea. Algae 33:101-108

Ingle KN, Polikovsky N, Chemodanov A, Golberg A (2018) Marine integrated pest management (MIPM) approach for sustainable seagriculture. Algal Res 29:223-232

Jia B, St-Hilaire S, Singh K, Gardner IA (2017) Biosecurity knowledge, attitudes and practices of farmers culturing yellow catfish (Pelteobagrus fulvidraco) in Guangdong and Zhejiang provinces, China. Aquaculture 471:146-156

Kamalakannan B, Jeevamani JJJ, Nagendran NA, Pandiaraja D, Chandrasekaran S (2014) Impact of removal of invasive species Kappaphycus alvarezii from coral reef ecosystem in Gulf of Mannar, India. Curr Sci 106:1401-1408

Kambey C, Chung IK (2016) A stella model for evaluating the efficiency of integrated multi-tropic aquaculture system (IMTA). Aquacult Indo 16:38-49

Kim GH, Moon KH, Kim JY, Shim J, Klochkova TA (2014) A revaluation of algal diseases in Korean Pyropia (Porphyra) sea farms and their economic impact. Algae 29:249-265

Kim JK, Yarish C, Hwang EK, Park M, Kim Y (2017) Seaweed aquaculture: cultivation technologies, challenges and its ecosystem services. Algae 32 (1): 1-13

Kirkpatrick JB, Kriwoken RK, Styge J (2019) The reverse precautionary principle: science, the environment and the salmon aquaculture industry in Macquarie Harbour, Tasmania, Australia. Pac Conserv Biol 25:26-33

Largo DB, Fukami K, Nishijima T, Ohno M (1995) Laboratory-induced development of the ice-ice disease of the farmed red algae Kappaphycus alvarezii and Eucheuma denticulatum (Solieriaceae, Gigartinales, Rhodophyta). J Appl Phycol 7:539-543

Largo DB, Chung IK, Pang SM, Gerung GS, Sondak CFA (2017) Impact of climate change on Eucheuma-Kappaphycus farming. In: Hurtado AQ, Critchley AT, Neish IC (eds) Tropical seaweed farming trends, problems and opportunities: focus on Kappaphycus and Eucheuma. Springer, Cham, pp 121-129

Lim PE, Tan J, Phang SM, Nikmatullah A, Hong DD, Sunarpi H, Hurtado AQ (2013) Genetic diversity of Kappaphycus Doty and Eucheuma J. Agardh (Solieriaceae, Rhodophyta) in Southeast Asia. J Appl Phycol 26:1253-1272

Loureiro R, Gachon CMM, Rebours C (2015) Seaweed cultivation: potential and challenges of crop domestication at an unprecedented pace. New Phytol 206:489-492
Loureiro RR, Hurtado AQ, Chritchley AT (2017) Impact of AMPEP on epiphytes and diseases in Kappaphycus and Eucheuma cultivation. In: Hurtado AQ, Critchley AT, Neish IC (eds) Tropical seaweed farming trends, problems and opportunities: focus on Kappaphycus and Eucheuma. Springer, Cham, pp 111-120

Malaysian Standard (2012) MS 2467/2012 seaweed cultivation-code of practices. Department of Standards, Malaysia $6 \mathrm{pp}$

Marino M, Breckwoldt A, Teichberg M, Kasec A, Reuter H (2019) Livelihood aspects of seaweed farming in Rote Island, Indonesia. Mar Policy 107:103600

Ministerial Regulation: Keputusan Menteri Kelautan dan Perikanan Republik Indonesia No 02 tahun 2007.Cara budidaya ikan yang baik. Jakarta, pp 1-11

Ministerial Regulation: Peraturan Menteri Kelautan dan Perikanan Republik Indonesia No 10 tahun 2012. Kewajiban tambahan karantina ikan. Jakarta, pp 1-8

Ministerial Regulation: Peraturan Menteri Kelautan dan Perikanan Republik Indonesia No 45 tahun 2015. Perubahan atas Peraturan Menteri Kelautan dan Perikanan Republik Indonesia Nomor 25/ PERMEN-KP/2015 tentang rencana strategis kementrian kelautan dan perikanan tahun 2015-2019. Jakarta, pp 1-92

Ministerial Regulation: Keputusan Menteri Tenaga Kerja Republik Indonesia No 107 tahun 2016. Penetapan standart kompetensi kerja nasional Indonesia kategori industri pengolahan gologan pokok industri makanan bidang usaha pengolahan rumput laut. Jakarta, pp 1-196

Ministerial Regulation: Peraturan Direktur Jendral Perikanan Budidaya Kementerian Kelautan dan Perikanan No. 217/PER-DJPB/2017. Petunjuk teknis bantuan kebun bibit rumput laut tahun 2018 . Jakarta, pp 1-26

Ministry of Marine Affair and Fisheries (MMAF-KKP) Republic of Indonesia (2002) Directorate General of Marine Fisheries Culture Report. Retrieved from http://www.indonesia.go.id/in/kementerian/ kementerian/kementerian-kelautan-dan-perikanan.htm on 15 April 2019

Ministry of Marine Affair and Fisheries (MMAF-KKP) online article (2019) FAO tunjuk Indonesia sebagai percontohan perbaikan tata kelola biosecurity perikanan budidaya. Retrieved from https://kkp. go.id/djpb/artikel/10906. htm on 15 April 2019

Morton A, Routledge R (2016) Risk and precaution: salmon farming. Mar Policy 74:205-212

National Legislation: Undang-Undang Republik Indonesia No.16 tahun 1992. Karantina hewan, ikan dan tumbuhan. Jakarta, pp 1-24

National Legislation: Undang-Undang Republik Indonesia No.31 tahun 2004. Perikanan. Jakarta, pp 1-86

National Legislation: Perubahan Undang-Undang Republik Indonesia No. 45 tahun 2009. Perikanan. Jakarta, pp 1-53

National Legislation: Undang-Undang Republik Indonesia No.7 tahun 2016. Perlindungan dan pemberdayaan nelayan, pembudidaya ikan dan petambak garam. Jakarta, pp 1-48

Neish IC (2013) Social and economic dimensions of carrageenan seaweed farming in Indonesia. In: Valderrama D, Cai J, Hishamunda $\mathrm{N}$, Ridler N (eds) Social and economic dimensions of carrageenan seaweed farming, vol 580. Fisheries and Aquaculture Technical Paper, FAO, Rome, pp 61-89

Neish IC, Sepulveda M, Hurtado AQ, Critchley AT (2017) Reflection of commercial development of Eucheumatoid seaweed farming. In: Hurtado AQ, Critchley AT, Neish IC (eds) Tropical seaweed farming trends, problems and opportunities: focus on Kappaphycus and Eucheuma. Springer, Cham, pp 1-27

Nor AM, Gray TS, Caldwell GS, Stead SM (2017) Is a cooperative approach to seaweed farming effectual? An analysis of seaweed cluster project (SCP), Malaysia. J Appl Phycol 29:2323-2337

Payne RD, Cook EJ, Macleod A (2014) Marine biosecurity planningguidance for producing site and operation-based plans for preventing the introduction of non-native species. Report by SRSL Ltd. in conjunction with Robin Payne to the Firth of Clyde Forum and Scottish National Heritage, pp 1-39 
Peteiro C, Sanchez N, Martínez B (2016) Mariculture of the Asian kelp Undaria pinnatifida and the native kelp Saccharina latissima along the Atlantic coast of Southern Europe: an overview. Algal Res 15:9-23

Phillips MJ, Subasinghe RP (2008) Application of risk analysis to environmental issues in aquaculture. In: Bondad-Reantaso MG, Arthur JR, Subasinghe RP (ed) Understanding and applying risk analysis in aquaculture. FAO Fisheries and Aquaculture Technical Paper No. 519. FAO, Rome, pp 101-119

Reddy CRK, Yokoya NS, Yong WTL, Luhan MRJ, Hurtado AQ (2017) Micro-propagation of Kappaphycus and Eucheuma: trends and prospects. In: Hurtado AQ, Critchley AT, Neish IC (eds) Tropical seaweed farming trend, problems and opportunities. Springer, Cham pp $91-110$

Rico A, Satapornvanit K, Haque MM, Min J, Nguyen PT, Telfer TC, Van den Brink VJ (2012) Use of chemical and biological product in Asian aquaculture and their potential environment risk: a critical review. Rev Aquac 4:75-93

Ritter C, Jansen J, Roche S, Kelton DF, Adams CL, Orsel K, Erskine RJ, Benedictus G, Lam TJGM, Barkema HW (2017) Invited review: determinants of farmers' adoption of management-based strategies for infectious disease prevention and control. J Dairy Sci 100:3329-3347

Rodgers CJ, Carnegie RB, Chavez-Sanchez MC, Martinez-Chavez CC, Furones Nozal MD, Hine PM (2015) Legislative and regulatory aspect of molluscan health management. J Invertebr Pathol 131:242-255

Sampaio FDF, Freire CA, Sampaio TVM, Vitule JRS, Favaro LF (2015) The precautionary principle and its approach to risk analysis and quarantine related to the trade of marine ornamental fishes in Brazil. Mar Policy 51:163-168

Scarfe AD (2003) State, regional, national, and international aquatic animal health policies: focus for future aquaculture biosecurity. In: Biosecurity in aquaculture production systems: exclusion of pathogens and other undesirables (ed) Lee CS, O'Bryen PJ. Baton Rouge, LA. The World Aquaculture Society, Baton Rouge, LA. pp 233-262

Sethi SA (2010) Risk management for fisheries. Fish Fish 11:341-365

Sondak CFA, Ang PO Jr, Beardall J, Bellgrove A, Boo SM, Gerung GS, Hepburn CD, Hong DD, Hu Z, Kawai H, Largo D, Lee JA, Lim PE, Mayakun J, Nelson WA, Oak JH, Pang SM, Sahoo D, Peerapornpis Y, Yang YF, Chung IK (2017) Carbon dioxide mitigation potential of seaweed aquaculture beds (SABs). J Appl Phycol 29:2363-2373

Standar Nasional Indonesia No.7579 (2010) Produksi rumput laut kotoni (Eucheuma cottonii). Badan Standardisasi Nasional (BSNI). Jakarta, pp 1-13

Standar Nasional Indonesia No. 7672 (2011) Bibit rumput laut kotoni (Eucheuma cottonii). Badan Standardisasi Nasional (BSNI). Jakarta, pp 1-7

Standar Nasional Indonesia No. 2690 (2015) Rumput laut kering. Badan Standardisasi Nasional (BSNI). Jakarta, pp 1-12

Standar Nasional Indonesia No. 8230 (2016) Prosedur biosecurity pada pembenihan ikan laut. Badan Standardisasi Nasional (BSNI). Jakarta, pp 1-16

Stentiford DG, Sritunyalucksana K, Flegel TW, Williams BAP, Withyachumnarnkul B, Itsathitphaisarn O, Bass D (2017) New paradigms to help solve the global aquaculture disease crisis. PLoS Pathog 13:e1006160

Stevant P, Rebours C, Chapman A (2017) Seaweed aquaculture in Norway: recent industrial development and future perspectives. Aquac Int 25:1373-1390

Sulu R, Kumar L, Hay C, Pickering T (2004) Kappaphycus seaweed in the Pacific: review of introductions and field testing proposed quarantine protocols. Noumea: Secretariat of the Pacific Community, pp $1-85$

Supriyadi H, Rukyani A (2000) The use of chemicals in aquaculture in Indonesia. In: Arthur JR, Lavilla-Pitogo CR, Subasinghe RP (ed.)
Use of chemicals in aquaculture in Asia: Proceedings of the Meeting on the Use of Chemicals in Aquaculture in Asia 20-22 May 1996, Tigbauan, Iloilo, Philippines, pp 113-118

Suwirya K, Giri NA (2018) Usaha pengembangan ikan kerapu sunu Plectopormus leopardus di Indonesia. J Riset Akua 12:307-314

Syafitri E, Prayitno SB, Ma'ruf WF, Radjasa OK (2017) Genetic diversity of the causative agent of ice-ice disease of the seaweed Kappaphycus alvarezii from Karimunjawa Island, Indonesia. IOP Conf. Series: Earth and Environmental Science 55-012044. https:// doi.org/10.1088/1755-1315/55/1/012044

Tano SA, Halling C, Lind E, Buriyo A, Wikstrom SA (2015) Extensive spread of farmed seaweeds causes a shift from native to non-native haplotypes in natural seaweed beds. Mar Biol 162:1983-1992

Thitamadee S, Prachumwat A, Srisala J, Jaroenlak P, Salachan PV, Sritunyalucksanaa K, Flegel TW, Itsathitphaisarn O (2016) Review of current disease threats for cultivated penaeid shrimp in Asia. Aquaculture 452:69-87

Thomsen MS, Wernberg T, Engelen AH, Tuya F, Vanderklift MA, Holmer M, McGlathery KJ, Arenas F, Kotta J, Silliman BR (2012) A meta-analysis of seaweed impacts on seagrasses: generalities and knowledge gaps. PLoS One 7:e28595

Troell M, Ronnback P, Halling C, Kautsky R, Buschman A (1999) Ecological engineering in aquaculture: used seaweeds for removing nutrients from intensive mariculture. J Appl Phycol 2:87-97

Unsworth RKF, Ambo-Rappe R, Jones BL, La Nafie YA, Irawan A, Hernawan UE, Moore AM, Cullen-Unsworth LC (2018) Indonesia's globally significant seagrass meadows are under widespread threat. Sci Total Environ 634:279-286

Valderrama D, Cai J, Hishamunda N, Ridler N, Neish IC, Hurtado AQ, Msuya FE, Krishnan M, Narayanakumar R, Kronen M, Robledo D, GascaLeyva E, Fraga J (2015) The economics of Kappaphycus seaweed cultivation in developing countries: a comparative analysis of farming systems. Aquac Econ Manag 19:251-277

Ward GM, Faisan-Jr JP, Cottier-Cook EJ, Gachon C, Hurtado AQ, Lim PE, Matoju I, Msuya FE, Bass D, Brodie J (2019) A review of reported seaweed diseases and pests in aquaculture in Asia. $\mathrm{J}$ World Aquat Soc DOI. https://doi.org/10.1111/jwas.12649

Whittington RJ, Chong R (2007) Global trade in ornamental fish from an Australian perspective: the case for revised import risk analysis and management strategies. Prev Ved Med 82:91-116

World Wide Fund for Nature (2014) Better management practices: Budidaya Rumput laut Kotoni (Kappaphycus alvarezii), Sacol (K.striatum) dan Spinosum (Eucheuma denticulatum).WWF Indonesia, pp 1-48

Yang Y, Chai Z, Wang Q, Chen W, He Z, Jiang S (2015) Cultivation of seaweed Gracilaria in Chinese coastal waters and its contribution to environmental improvements. Algal Res 9:236-244

Yong WTL, Ting SH, Yong YS, Thien VY, Wong SH, Chin WL, Rodrigues KF, Anton A (2014) Optimization of culture conditions for the direct regeneration of Kappaphycus alvarezii (Rhodophyta, Solieriaceae). J Appl Phycol 26:1597-1606

Yulianto K (2004) Fenomena faktor pengontrol penyebab kerugian pada budidaya karaginofit di Indonesia. Oceano 29:17-23

Zemke-White LW, Smith JE (2006) Environmental impact of seaweed farming in the tropics. In: Critchley AT, Ohno M, Largo D (ed) World seaweed resources. Expert Center for Taxonomic Identification (ETI), University of Amsterdam

Zuccarello GC, Critchley AT, Smith JE, Sieber V, Bleicher-Lhonneur G, West JA (2006) Systematic and genetic variation in commercial Kappaphycus and Eucheuma (Solieriaceae, Rhodophyta). J Appl Phycol 18:643-651

Publisher's note Springer Nature remains neutral with regard to jurisdictional claims in published maps and institutional affiliations. 